\section{Comentários ao artigo: itinerários \\ e métodos do aborto ilegal \\ em cinco capitais brasileiras}

Comments on the article: itineraries

and methods of illegal abortion

in five Brazilian state capitals

M aria Andréa Loyola ${ }^{1}$

É muito bem vindo eoportuno o artigo de Diniz eM edeiros - Itinerários emétodos do aborto ilegal em cinco capitais brasileiras - publicado neste número da Revista Ciência \& Saúde Coletiva. Realizado a partir de entrevistas estruturadas com mulheres que levaram a termo abortos ilegais, em cinco capitais brasileiras. Este trabal ho complementa, aprofundando, as etapas anteriores do primeiro estudo sistemático sobre o aborto no Brasil, publicado pelos mesmos autores. Ambos os estudos nos informam o quão forte e generalizada é a cultura do aborto em todas as regiões do país e quão limitado é nosso conhecimento sobre a realidade desta prática. Evidentemente que esse vazio de informações decorre do fato de tratar-se de tema legalmente criminalizado e objeto de acaloradas controvérsias, ainda que tenha sido tratado, em revisão sistemática coordenada e publicada pelo M inistério da Saúde em 2009르, como um problema desaúde pública. Além de seu pioneirismo, o grande mérito do trabalho de Diniz e M edeiros foi ter enfrentado de forma corajosa a abordagem deste tema.

Do ponto de vista ético emetodológico o trabalho é impecável. Os autores não somente inovam em matéria da metodologia aplicada, como se cercam de vários e criativos recursos para garantir o sigilo em torno das identidades das informantes, assim como, a neutralidade possível do local das entrevistas e dos procedimentos dos entrevistadores. 0 estudo, aprovado por vários comitês deética em pesquisa, constitui, em si mesmo, um modelo de pesquisa com ética em ciências humanas e da saúde.

Orientados pelo mesmo rigor com que realizaram o trabalho, os autores advertem insistentementeque estão ser eferindo a um universo restrito (às 122 mulheres que foram entrevistadas) e que suas conclusões não podem ser generalizadas. Isso não impede que algumas delas sejam transformadas em hipóteses a serem exploradas por eles mesmos ou por outros pesquisadores. Ainda mais, porque o rico e raro conhecimento por eles colocado em evidencia, confirma resultados de trabalhos anteriores mais pontuais, con- tribuindo, assim, paradiminuir significativamente a área de sombra que paira sobre o tema.

Tudo indica, pois, que os itinerários das muIheres que abortaram, embora apresentem variações regionais, por idade, cor e escolaridade, não diferem significativamenteno que diz respeito ao percurso e, principalmente, aos métodos utilizados. Todos esses itinerários tem como ponto de partida um diagnóstico seguramente configurado da gravidez e desembocam em um procedimento abortivo ao término de aproximadamente dois meses, após a suspensão das regras.

Grande parte das mulheres entrevistadas usam diferentes combinações de ervas e medicamentos popularmente consagrados antes da ingestão do medicamento Cytotec. Outras vezes, 0 ingerem diretamente. Em todos os casos, o medicamento éfornecido em embalagens não identificadas, procedimento que se coaduna com a clandestinidade de seu destino.

São também recorrentes o sofrimento descrito pelas mulheres durante a noite em que aguardam o efeito abortivo do cytotec e seu desaparecimento do sangue para evitar queo aborto seja reconhecido como tendo sido provocado. Acrescenta-se a esta dolorosa espera os maus tratos por parte de alguns médicos, quando estes percebem que 0 aborto não foi espontâneo. Percorrer itinerários de dores físicas e psicológicas só se justifica se a gravidez é indesejada.

$E$, não obstante o cuidado dos autores para evitar ou sugerir interpretações quando os indíciossão insuficientes, podemosinferir dos dados que eles apresentam que existe uma gradação na prática do aborto no que se refere à motivação das mulheres que o praticam, embora essas motivações provavelmente não sejam excludentes: aqueles efetuados pelas adolescentes, tudo indica, se relacionam a ausência de uma sexualidade protegida; os praticados por mulheres negras e por prostitutas a condições econômicas e sociais insuficientes para levar a termo a gravidez eaqueles realizados por mulheres brancas, mais velhas ecom mai or escolaridade a um desejo consciente de limitar o numero de filhos,

Chama a atenção, secundariamente, a semeIhança de certas práticas utilizadas por uma parte das mulheres entrevistadas com aquelas da medicina popular, tais como o uso de chás, o sangue 
como depositário dos males e da cura orgânica e ao jejum, popularmente associado à limpeza e ao bom funcionamento do corpo, observado antes do inicio do processo abortivo; práticas correntes entreas populações de baixa ren da ebaixa escolaridade$^{2}$; e, neste estudo, às mulheres negras. Poderíamos indagar setais práticas persistiriam caso 0 aborto pudesse ser abertamente acolhido pela medicina. Embora Diniz eM edeiros seabstenham de fazer ilações a este respeito, parece bastante provável que as religiões propriamente ditas não constituem barreiras suficientemente fortes às práticas do aborto. E isto porque, nas palavras dos autores: a rapidez e a facilidade com que uma mulher aciona uma ampla rede de cuidados e dispositivos para abortar é um dos sinais de como a cultura do aborto é compartilhada entre as mulheres no Brasil. Não há como descrevê la como uma cultura secreta, pois as semel hanças encontradas entre mulheres tão diferentes mostra que é uma cultura feminina clandestina à restrição legal, mas transmitida entre diferentes gerações.

De fato, a presença de mães, amigas e companheiros (e porque não dizer, também dos médicos que as atendem nos hospitais públicos e nas clinicas privadas) nos itinerários descritos por Diniz e M edeiros demonstra que 0 aborto clandestino constitui uma prática desde há muito integrada ao processo reprodutivo das mulheres brasileiras. Embora uma parte da população talvez não discorde daqueles que classificam o aborto como um ato pecaminoso e antinatural, para as mulheres que o praticam ao risco de suas próprias vidas e para por suas famílias ele parece ser visto como um transtorno, ainda queindesejável, por vezes fundamentalmente necessário. Muitos embates políticos serão ainda necessários para evitar estes itinerários clandestinos e arriscados trazidos à luz pelo corajoso trabal ho de Diniz e M edeiros. 0 próprio artigo desses autores, assim como outros incluídos neste número especial temático da Revista Ciência \&Saúde Coletiva constituem certamente um passo nesta direção.

\section{Referências}

1. Brasil. Ministério da Saúde (MS). Aborto e Saúde Pública no Brasil: 20 anos. Brasília: M S; 2009. (Série B. Textos Básicos de Saúde)

2. Loyola MA. M édicos e curandeiros. Conflito social e saúde. São Paulo: DIFEL; 1984. 